\title{
PELATIHAN “FUN WITH ENGLISH” UNTUK SISWA SMP SEBAGAI UPAYA PENINGKATAN KEMAMPUAN BAHASA INGGRIS
}

\author{
Pratika Ayuningtyas* \\ Politeknik Sawunggalih Aji, Purworejo, Indonesia \\ *Penulis Koresponsensi, email: pratika.ayuningtyas@gmail.com
}

Abstract. English is a global language which students should master to be able to be part of global world. Many hinders in learning English made the government and the education institution should work together in solving this problem. A short course namely Fun with English then proposed to omit the problem. The purpose of this course was to improve students' communication skills in using English as well as improving their motivation and confidence. The program was done for two months. The participant of this program was the students from the nearby junior high school. After finishing the program students felt motivated less anxious and more confident in using English as their everyday language. It is expected that the similar program could be done regularly.

Keywords: English, Fun learning, Training, Joined program

\begin{abstract}
Abstrak. Bahasa Inggris adalah bahasa global yang harus dipahami oleh setiap peserta didik agar dapat menjadi bagian dari dunia global sekarang ini. Hal in imengharuskan pemerintah Bersama dengan Lembaga Pendidikan harus bekerja sama agar para siswa dapat menguasai bahasa Inggris. Pelatihan yang diberi judul Fun With English diajukan untuk membantu menyeleaikan masalah tersebut. Tujuan dari pelatihan in adalah untuk meningkatkan kemampuan berkomunikasi siswa dalam menggunakan bahasa Inggris serta meningkatkan motivasi belajar dan juga kepercayaan diri. Program pelatihan ini dilaksanakan dalam waktu dua bulan. Peserta pelatihan adalah siswa SMP dari sekolah terdekat dengan kantor DINARPUSDA. Setelah pelatihan selesai, para siswa merasa lebih termotivasi dan tidak lagi cemas serta lebih percaya diri dalam berbicara dengan Bahasa Inggris sebagai bahasa asing yang mereka bbisa gunakan sehari-hari. Diharapkan program semacam ini dapat diadakan secara rutin.
\end{abstract}

Kata Kunci: Bahasa Inggris, Belajar menyenangkan, Pelatihan, Program kerja sama

How to Cite: Ayuningtyas, P. (2021). Pelatıhan "Fun with English" Untuk Siswa SMP Sebagai Upaya Peningkatan Kemampuan Bahasa Inggris. Mitra Mahajana: Jurnal Pengabdian Masyarakat, 2(2), 161-169. https://doi.org/10.37478/mahajana.v2i2.851

\section{PENDAHULUAN}

Menurut UU no 20 tahun no 2003, masyarakat harus berperan serta secara aktif dalam perencanaan, perencanaan, pengawasan evaluasi program Pendidikan. Selain itu, masyarakat juga bertanggung jawab dalam menyelenggarakan pendidikan sesuai dengan sumber daya yang disanggupinya (Nasional, 1982). Pendidikan merupakan tanggung jawab bersama masyarakat Indonesia, baik dalam suatu organisasi maupun perorangan. Sebagai salah satu instansi perguruan tinggi yang berada di Kabupaten Purworejo, Politeknik Sawunggalih aji memiliki tanggung jawab untuk memajukan Pendidikan, khususnya di Kabupaten Purworejo. Dengan menggandeng instansi pemerintahan, tentunya lebih mudah bagi pihak kampus untuk dapat melakukan penetrasi terhadap kegiatan-kegiatan masyarakat.

Dinas Arsip dan Perpustakaan Daerah Kabupaten Purworejo merupakan instansi yang berada pada satu kecamatan dengan kampus Politeknik Sawunggalih Aji. DINARPUSDA memiliki program kerja yang salah satunya adalah mengajak warga masyarakat untuk lebih giat membaca dan berkegiatan di perpustakaan daerah. Dengan adanya tujuan tersebut maka DINARPUSDA meminta Politeknik Sawunggalih Aji agar membuat kegiatan sebagai salah satu cara agar masyarakat dapat meramaikan perpustakaan.

Berbekal tujuan yang sama maka DINARPUSDA bersama dengan Politeknik Sawunggalih Aji mengejawantahkan undang-undang tersebut dengan membuat program yang berorientasi terhadap kebutuhan masyarakat. Politeknik Sawunggalih Aji kemudian menyelenggarakan kegiatan pengabdian kepada masyarakat. Kegiatan pengabdian masyarakat tentunya harus dapat meningkatkan kesejahteraan hidup masyarakat dalam berbagai aspek. Salah satunya adalah aspek Pendidikan untuk meningkatkan kesejahteraan. Pendidikan dianggap sebagai 
salah satu factor untuk meningkatkan kesejahteraan seseorang. Seseorang dengan tingkat Pendidikan lebih tinggi umumnya lebih sejahtera (Aini et al., 2018; Widyastuti, 2012).

Berdasarkan hal tersebut maka salah satu cabang Pendidikan yang dipilih dalam pelatihan ini adalah pelatihan berbahasa yang mana secara langsung dapat mempengaruhi kemampuan berkomunikasi seseorang. Bahkan di era 4.0 yang sebentar lagi menjadi era 5.0 ini, kemampuan berbahasa harus ditingkatkan dua kali lipat agar seseorang dapat berkomunikasi dengan lebih baik lagi (Latifah, 2019).

Kemampuan bahasa adalah yang sering diasosiasikan sebagai kemampuan intelektual seseorang. Bahasa merupakan salah satu hal yang sangat dibutuhkan dalam menumbuhkan kemampuan professional seseorang (Lestari, 2019). Salah satu yang dapat dilihat dalam language skills (kemampuan berbahasa) seseorang adalah dengan menguasai bahasa asing. Salah satu bahasa asing yang paling penting di dunia adalah Bahasa Inggris. Bahasa ini merupakan lingua franca, yaitu bahasa yang memiliki penutur terbanyak. Diharapkan jika seseorang memiliki kemampuan berbahasa inggris, maka peluang di masa depan untuk bersaing mendapatkan hidup yang lebih baik akan meningkat (Tamrin \& Yanti, 2019).

Bahasa Inggris menjadi bahasa asing yang dapat dikatakan sebagai bahasa asing yang wajib dikuasai oleh siswa, namun bahasa Inggris adalah salah satu mata pelajaran yang diaggap sukar oleh sebagian besar siswa pada hampir semua jenjang pendidikan. Anggapan tersebut tentunya memiliki dampak kurang baik terhadap hasil belajar, motivasi dan minat siswa (Alek, 2014). Namun tidak bisa dipungkiri, bahawa bahasa Inggris merupakan Bahasa global yang dipakai di seluruh dunia. Apabila siswa mahir berbahasa Inggris, diharapkan para siswa telah siap menghadapi kompetisi yang semakin ketat di era globalisasi (Risnawaty, 2018). Bertujuan untuk meningkatkan kemampuan siswa agar lebih siap menghadapi era globalisasi, maka pelatihan ini diajukan sebagai salah satu cara untuk menyelesaikan masalah tersebut.

Beberapa hasil dari pengabdian mengenai pelatihan Bahasa Inggris menunjukkan bahwa peserta didik mengalami peningkatan kemampuan Bahasa Inggris, seperti pada pengabdian tahun 2018 yang dilaksanakan di Bandung yang menyimpulkan bahwa berdasarkan evaluasi yang diperoleh, mahasiswa yang mengikuti Pelatihan Bahasa Inggris Dasar mengalami peningkatan kemampuan Bahasa Inggrisnya. Oleh karena itu, program seperti ini perlu untuk dilaksanakan guna membantu peserta didik agar memiliki daya saing yang baik. (Permata \& Hsdiani, 2018)

Selain peningkatan kemampuan, meningkatnya minat belajar bahasa Inggris juga dialami peserta didik yang memperoleh pelatihan pada tahun 2019 di Kabupaten Sidrap. Berdasarkan hasil pengabdian, dapat disimpulkan bahwa pelatihan bahasa Inggris di wilayah ini sangat bermanfaat dan menarik minat dari para peserta. Karena anak-anak dan para pemuda sangat berpeluang dan mampu menyerap pelajaran yang telah diberikan dengan baik. Hal ini dapat terlihat dari antusiasme mereka dalam proses belajar dan terjadinya suatu kegiatan yang lebih berguna setelah adanya kegiatan pengabdian ini.(Tamrin \& Yanti, 2019)

Berdasarkan materi dasar yang diberikan, pengabdian tahun 2017 yang dilakukan di Palangkaraya menyimpulkan bahwa pemilihan materi pelatihan yang mencakup skil- skil dasar yang berguna untuk menunjang kemampuan berkomunikasi baik lisan maupun tertulis. Pelatihan Bahasa Inggris merupakan salah satu upaya positif dan nyata yang dapt dilakukan untuk meningkatkan kemampuan penguasaan Bahasa Inggris (Suniati et al., 2017).

Maka secara umum dapat disimpulkan, program pelatihan bahasa Inggris dapat memberikan dampak positif dalam berbagai aspek, antara lain: aspek social, ekonomi dan Pendidikan baik bagi peserta didik maupun pengajarnya (Warman et al., 2020)

Berdasarkan berbagai hasil dari pengabdian tersebut, maka Politeknik Sawunggalih Aji bekerja sama dengan Dinas Arsip dan Perpustakaan Daerah Kabupaten Purworejo menyelenggarakan sebuah program "Fun with English" yaitu sebuah program yang mengajak para siswa sekolah menengah pertama di sekitar kantor DINARPUSDA untuk meningkatkan 
kemampuan berbahasa Inggris dengan metode smart dan fun, dengan memberikan pelatihan Bahasa Inggris dengan metode yang menyenangkan.

Tujuan dari kegiatan ini adalah membantu siswa dalam penguasaaan Bahasa Inggris yang baik dan benar, membantu dalam mengatasi kesulitan belajar yang dihadapi siswa di sekolah, memberikan sistem pengajaran yang mudah dalam penyampaian materi sehingga mempermudah penguasaan materi, dan meningkatkan kemampuan komunikasi Bahasa Inggris dengan baik dan benar.

\section{METODE PELAKSANAAN}

Pada awalnya, pihak DINARPUSDA bergerak ke lapangan terlebih dahulu dengan menghubungi pihak sekolah menengah pertama terdekat untuk mencari tahu informasi mengenai jumlah siswa serta jadwal sekolah berakhir setiap harinya. Pihakn DINARPUSDA menunjuk dua sekolah terdekat untuk mengikuti program ini. Kemudian Pihak DINARPUSDA Bersama dengan Politeknik Sawunggalih Aji membuat jadwal terstruktur untuk melaksanakan program tersebut agar setiap sekolah mendapatkan kesempatan yang sama. Pelaksanaan kegiatan "Fun with English" adalah selama tiga kali pertemuan untuk masing-masing sekolah yang diundang.

Ada dua sekolah yang diundang pada program ini, yaitu SMP N 3 Purworejo dan SMP N 16 Purworejo. Masing-masing sekolah diminta untuk mengirimkan minimal 10 anak untuk mengikuti kegiatan ini. Masing-masing sekolah mendapatkan jadwal tersendiri selama program berlangsung. Program ini dilaksanakan selama kurang lebih dua bulan, mengingat jadwal hanya dilaksanakan pada hari Jumat setiap pulang sekolah dari pukul 10.30 sampai dengan pukul 11.30. Setiap kelompok dari masing-masing sekolah mendapatkan jatah pertemuan sebanyak tiga kali pertemuan.

Selama tiga kali pertemuan, masing masing kelompok dari sekolah yang diundang akan mendapatkan materi yang sama dari para pengajar. Materi tersebut berupa materi bahasa Inggris dasar yang mencakup greeting, introduction, parting serta tambahan materi reading sebagai salah satu skill bahasa yang harus dikuasai. Semua siswa juga mendapat jatah waktu belajar yang sama yaitu selama satu jam (60 menit). Dengan menggunakan metode belajar yang menyenangkan para siswa tidak dibebani oleh nilai dan evaluasi, namun lebih kepada peningkatan kepercayaan diri dalam menggunakan Bahasa Inggris.

Metode pengajaran yang digunakan dalam pelatihan ini adalah metode belajar menyenangkan. Metode ini memudahkan pengajar untuk memperbaiki proses pembelajaran, yaitu dengan memecah proses ke dalam langkah-langkah atau tahapan-tahapan secara terperinci yang memuat instruksi untuk peserta didik melaksanakan kegiatan pembelajaran (Layyinah, 2017). Pada prakteknya, dalam tiap pertemuan terdiri dari beberapa langkah atau tahapan-tahapan. Langkah-langkahnya adalah:

\section{Background Knowledge}

Pada setiap pertemuan siswa akan diberikan background knowledge mengenai materi yang akan diberikan. Maka siswa tidak merasa asing dengan materi yang akan dipelajari pada hari itu.

2. Modelling

Memberikan contoh nyata dalam tiap materi pembelajaran. Seorang pengajar hendaknya mampu memberikan contoh yang baik agar siswa mampu merekam hal tersebut untuk kemudian dapat dijadikan referensi bagi siswa.

3. Collaboration

Siswa diberikan kesempatan untuk bekerjasama menyelesaikan masalah. Dalam menyelesaikan soal maupun tugas, siswa diberikan kesempatan untuk bekerja sama 
dalam kelompok kecil amupun besar. Hal ini bertujuan agar siswa yang sudah paham dapat membantu siswa yang belum atau kurang paham.

4. Independent Learning

Setelah mendapat contoh dari pengajar serta setelah bekerja sama dengan teman sebaya, diharapkan siswa mampu menyelesaikan masalah secara mandiri.

Selain itu pengajar juga harus menyapa siswa dengan ramah dan penuh semangat. Semangat dan keramahan dari pengajar akan memberikan efek positif terhadap siswa. Selain itu, pengajar harus menciptakan suasana kelas yang kondusif, salah satu contohnya adalah dengan memperdengarkan cerita, menyetel cuplikan film, dan mengatur tempat duduk senyaman mungkin. Memotivasi para peserta didik juga merupakan hal yang penting dilakukan, misalnya dengan memberikan hadiah kecil sebagai bentuk apresiasi karena telah menjawab pertanyaan, atau sudah berani presentasi di depan kelas. Selain ketiga hal diatas, penggunaan metode yang variative (bermacam-macam) juga semestinya dilakukan sebagai syarat pembelajaran menyenangkan. Pengajar bersifat sebagai mediator, bukan sebagai satu-satunya sumber ilmu. Metode ceramah hanya sedikit dilakukan. Tanya jawab, diskusi dan praktek lebih banyak dilakukan (Layyinah, 2017).

Metode pengajaran tersebut diharapkan mampu meningkatkan kemampuan siswa dalam berbahasa Inggris. Dengan adanya siswa yang menghadiri program ini, maka jumlah pengunjung di kantor DINARPUSDA juga meningkat. Hal ini tentunya menjadi baik karena makin banyak orang yang mengenal DINARPUSDA sebagai salah satu tempat nyaman untuk belajar dan mencari referensi Ketika menulis.

\section{HASIL DAN PEMBAHASAN}

Peserta program ini adalah siswa dari dua sekolah terdekat dari kantor DINARPUSDA yaitu SMP N 3 Purworejo dan SMP N 16 Purworejo. Kedua sekolah menengah tersebut adalah merupakan sekolah unggulan, terutama SMP N 3 Purworejo. Yang mana merupakan sekolah tiga teratas dalam peringkat di Kabupaten Purworejo. Dengan memilih sekolah sekolah yang memiliki kualitas bagus, diharapkan lebih mudah memberikan mindset positif mengenai pentingnya membaca sejak dini. - yang mana merupakan salah satu tujuan diadakannya pelatihan ini.

SMP N 3 Purworejo berlokasi kurang lebih 200-meter dari kantor DINARPUSDA kabupaten Purworejo. Tepatnya di sebelah utara dari Gedung DINARPUSDA. Sedangkan SMP N 16 berlokasi sekitar 400-meter dari kantor DINARPUSDA ke arah barat daya. Kedua sekolah tersebut sengaja dipilih karena lokasi yang memang berdekatan dengan kantor DINARPUSDA.

Masing-masing sekolah mengirimkan peserta didik untuk mengikuti pelatihan ini. Peserta dari SMP N 3 Purworejo berjumlah 12 siswa sedangkan peserta dari SMP N 16 Purworejo berjumlah 25 siswa. Detail daftar peserta dapat dilihat pada Tabel 1 dibawah.

Tabel 1. Daftar Peserta Fun With English

\begin{tabular}{|c|c|c|c|c|}
\hline No & Peserta & Jumlah & Hari dan Tanggal & Materi \\
\hline \multirow[t]{3}{*}{1} & SMP N 3 PURWOREJO & 12 siswa & $4-11-2016$ & Greeting \\
\hline & & & 11-11-2016 & Daily Routine \\
\hline & & & $28-12-2016$ & Smart Reading \\
\hline \multirow[t]{3}{*}{2} & SMP N 16 PURWOREJO & 25 siswa & 18-11-2016 & Greeting \\
\hline & & & 25-11-2016 & Daily Routine \\
\hline & & & $2-12-2016$ & Smart Reading \\
\hline
\end{tabular}


Pelatihan dilaksanakan setiap siswa pulang sekolah, jadi tidak mengganggu kelangsungan belajar-mengajar di sekolah masing-masing. Dipilihnya sekolah dengan jarak yang dekat tersebut juga bukan tanpa alasan. Pemilihan kedua sekolah tersebut mempertimbangkan tidak habisnya waktu yang dihabiskan siswa untuk menghadiri pelatihan karena jarak. Siswa dapat berjalan kaki ke kantor DINARPUSDA sepulang sekolah untuk mengikuti pelatihan. Maka siswa tidak terbebani oleh biaya angkutan, dan lain sebagainya.

Peserta program adalah berdasarkan undangan yang diberikan, jadi tidak setiap siswa dari SMP tersebut dapat mengikuti program, namun sekolah masing-masing yang menentukan siapa saja yang berhak mengikuti program ini. Hal ini dikarenakan ruangan tempat diadakannya program terbatas, jadi peserta yang mengikuti program pun harus dibatasi sesuai dengan Permendinas No 24 tahun 2007 (Naoum, 2007). Selain mempertimbangkan hal tersebut, pertimbangan lainnya adalah jumlah peserta yang terbatas memungkinkan para peserta didik untuk memahami materi lebih baik. Untuk para pengajar tentunya materi pelatihan dapat disampaikan lebih baik, serta dapat lebih memperhatikan peserta didik. Berikut adalah gambar ruangan pelatihan yang ada di DINARPUSDA.

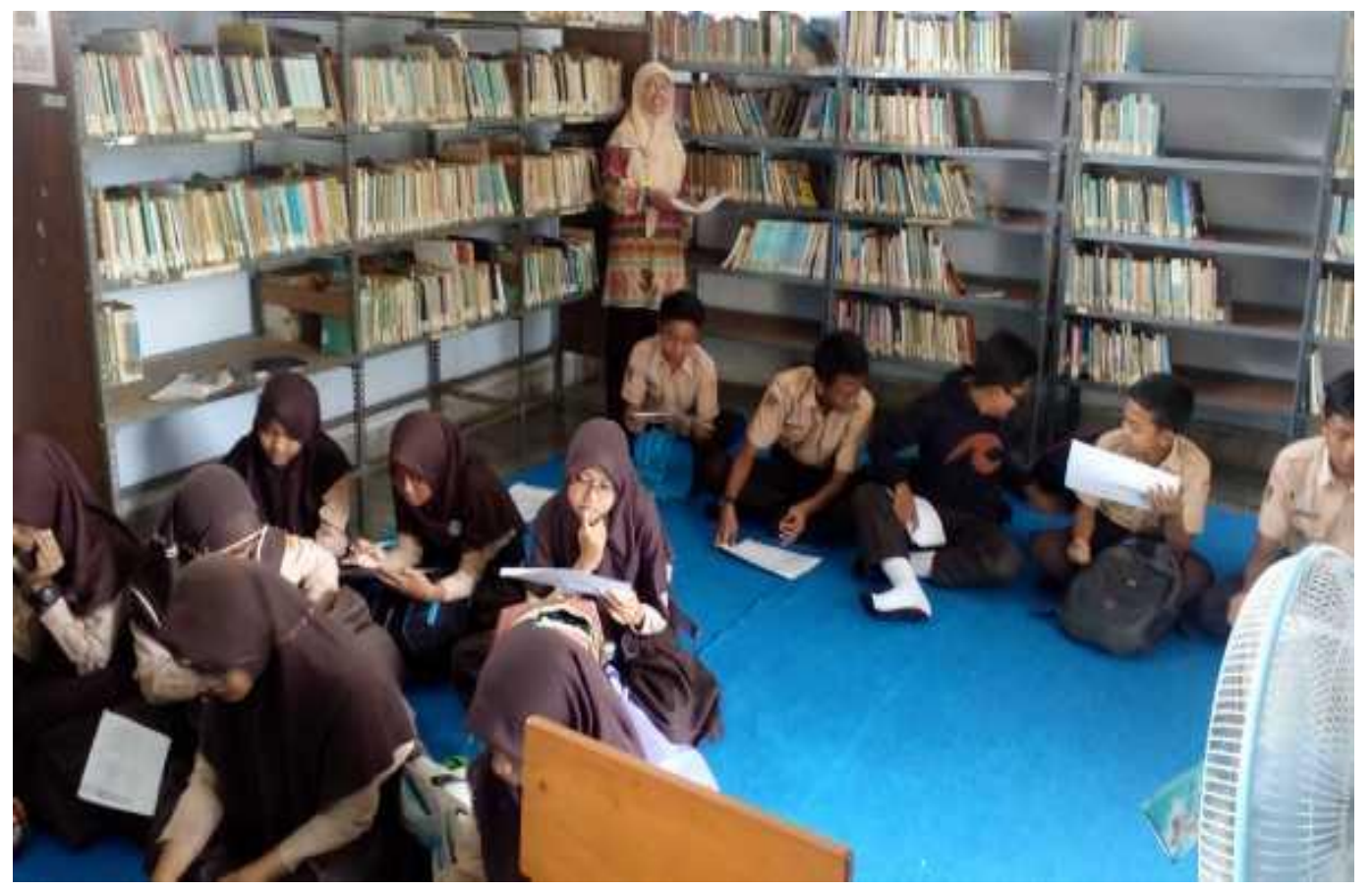

Gambar 1. Ruangan Pelatihan

Metode kegiatan pengabdian pada masyarakat ini adalah berupa pelatihan bahasa Inggris untuk meningkatkan kemampuan berbahasa Inggris mereka dalam berkomunikasi. Pelatihan fokus kepada skill berbicara yang meliputi language expression dan kosa kata, pengucapan, tata bahasa dan kelancaran berbicara. Menggunakan metode belajar menyenangkan, pelatihan selalu dimulai dengan menanyakan kabar dan bercerita mengenai kejadian yang terjadi di sekolah. Hal ini bertujuan untuk mengurangi ketegangan maupun tekanan dalam mengikuti pelatihan. Peserta didik yang menikmati waktu belajarnya akan menyerap materi lebih baik disbanding peserta didik yang tegang dan dibawah tekanan.

Dalam tahap background knowledge peserta didik diberikan cerita, menonton cuplikan film dan juga sharing mengenai pengalaman mengenai materi yang pernah dialami dalam kehidupan sehari-hari. Pada tahap modelling, salah satu metode yang digunakan yaitu metode drilling menjadi salah satu cara yang efektif dipakai untuk membiasakan para siswa dalam menjawab pertanyaan maupun melakukan percakapan dalam Bahasa Inggris (Andy et al., 2018). Dalam hal ini pengajar akan memberikan contoh pengucapan kata, misalnya "how are you?" dengan ucapan dan intonasi yang tepat. Para peserta kemudian menirukan dan 
mengulang-ulang untuk mencapai ucapan dan intonasi yang tepat tersebut. Metode drilling seperti ini diklaim mampu untuk meningkatkan kemampuan bahasa peserta sebanyak tiga kali lipat dari sebelum mendapatkan metode ini (Elly, 2013)

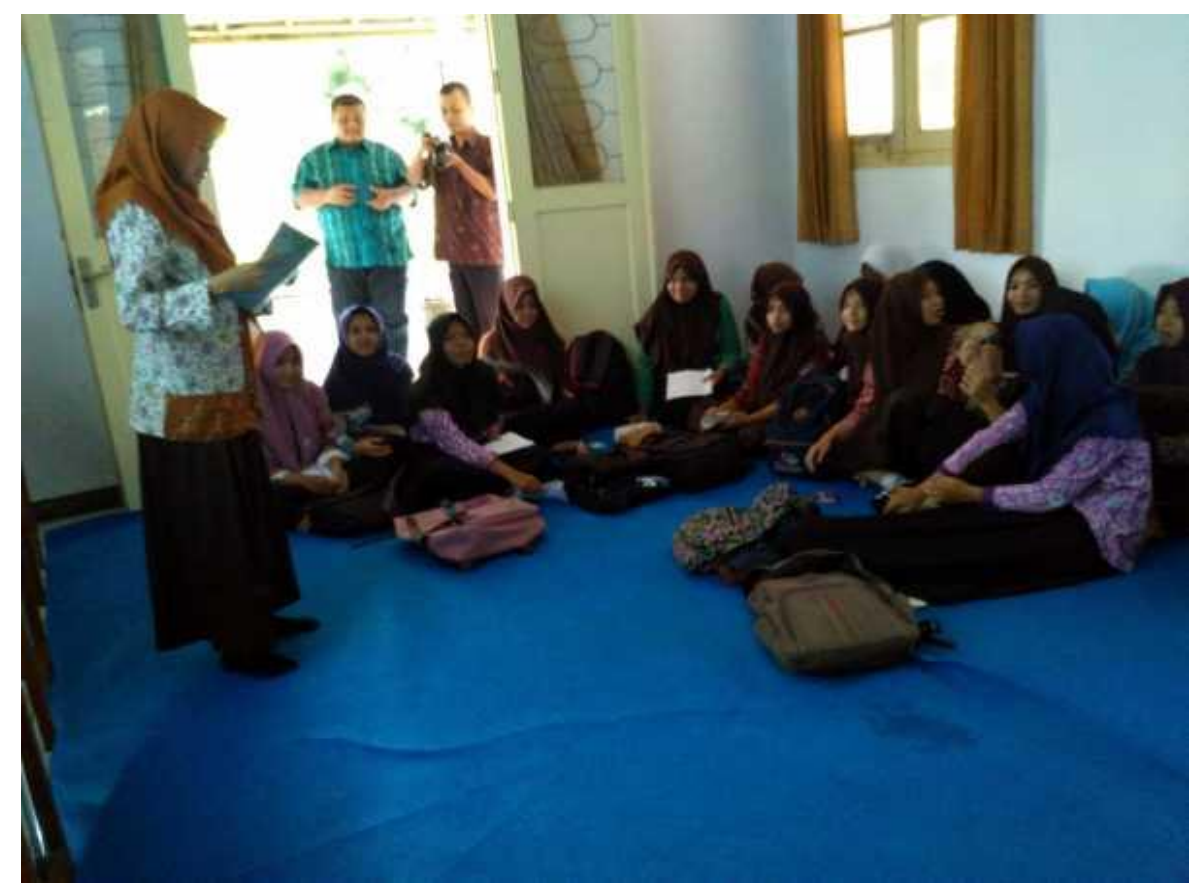

Gambar 2. Drilling dipandu oleh trainer

Tahapan selanjutnya yaitu tahap joint construction dimana peserta bekerja sama untuk menyelesaikan masalah. Dalam hal ini peserta didik akan melakukan role play secara berpasangan, dengan pendampingan dari pengajar untuk mengoreksi kesalahan-kesalahan dalam pronunciation maupun intonation. Dengan memberikan contoh di depan kelas secara bergantian, diharapkan peserta didik mengerti dan memahami mengenai bagaimana harus melafalkan kata maupun kalimat yang baik dalam bahasa Inggris.

Tahap terakhir adalah independent construction dimana peserta didik menyelesaikan masalah sendiri tanpa bantuan dari teman, maupun pengajar. Maksudnya adalah peserta didik secara mandiri menyelesaikan masalah tanpa harus bergantung terhadap orang lain. Yang dilakukan pada tahapan ini adalah peserta didik diminta untuk menjawab beberapa pertanyaan terkait dengan materi yang sudah diberikan. Peserta didik juga diminta Menyusun percakapan yang berterima sebagai tolak ukur bahwa peserta didik paham akan materi yang telah diberikan.

Dalam mengikuti kegiatan ini, terlihat adanya motivasi peserta yang tinggi, hal ini dapat dilihat dari keaktifan mereka dalam mengikuti pelatihan. Beberapa peserta aktif menyimak dan sesekali bertanya kepada pengajar. Para peserta mendapatkan handout gratis yang diterima pada saat pelatihan. Pemberian materi handout, media pembelajaran dan sarana belajar yang disiapkan oleh institusi atau lembaga penyelenggara pelatihan terbukti berdampak positif dalam pengenalan bahasa Inggris (Muliyah \& Fernando, 2019)Handout atau modul diberikan agar peserta mendapatkan referensi yang dapat digunakan kembali apabila dibutuhkan di lain hari. Handout disusun demikian rupa dengan ilustrasi yang menarik dengan Bahasa yang mudah dipahami serta memiliki keterbacaan yang baik untuk meningkatkan pemahaman peserta. Handout yang disusun juga jelas dengan konsep yang tidak membingungkan. Hal ini akan memberikan motivasi peserta untuk membacanya (Cahyati, 2015).

Setelah mendapatkan handout atau modul peserta kemudian menyimak penjelasan pengajar seperti yang terlihat dalam Gambar 3 berikut. 


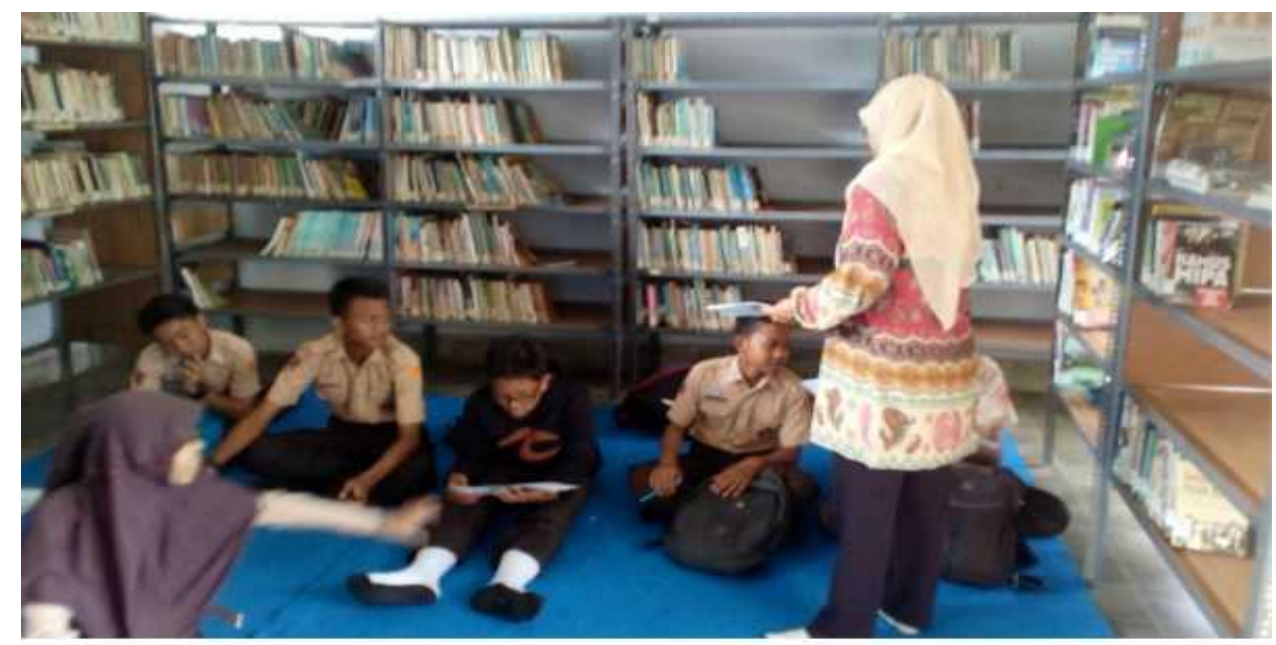

Gambar 3. Peserta menyimak Modulyang diberikan oleh trainer

Handout berisi contoh percakapan yang biasa digunakan sehari-hari dengan menggunakan Bahasa Inggris tanpa ada arti dalam Bahasa Indonesia. Hal tersebut berkaitan dengan tujuan adanya pelatihan Bahasa Inggris yang mana adalah meningkatkan kemampuan berkomunikasi para peserta. Dengan adanya handout yang dibuat berbahasa Inggris, peserta akan memiliki keingintahuan yang besar untuk memahami materi dari handout. Pada saat kegiatan berlangsung, pengajar menggunakan Direct Method dalam menyampaikan materi. Metode ini terbukti dapat meningkatkan kemampuan berbicara dalam Bahasa Inggris (Hulu \& Ambalegin, 2018). Metode tersebut juga memberikan pengalaman langsung kepada para peserta pelatihan dengan lengsung menggunakan Bahasa Inggris tanpa harus memikirkan susunan tata bahasanya. Dengan memberikan pengalaman langsung ini peserta pelatihan merasa dilibatkan dalam proses belahar dan membuat mereka bertanggung jawab terhadap hasilnya (Risnawaty, 2018).

Contoh halaman handout yang diterima siswa dan yang ditayangkan pada slide adalah seperti pada Gambar 4 berikut.

\section{Greeting}

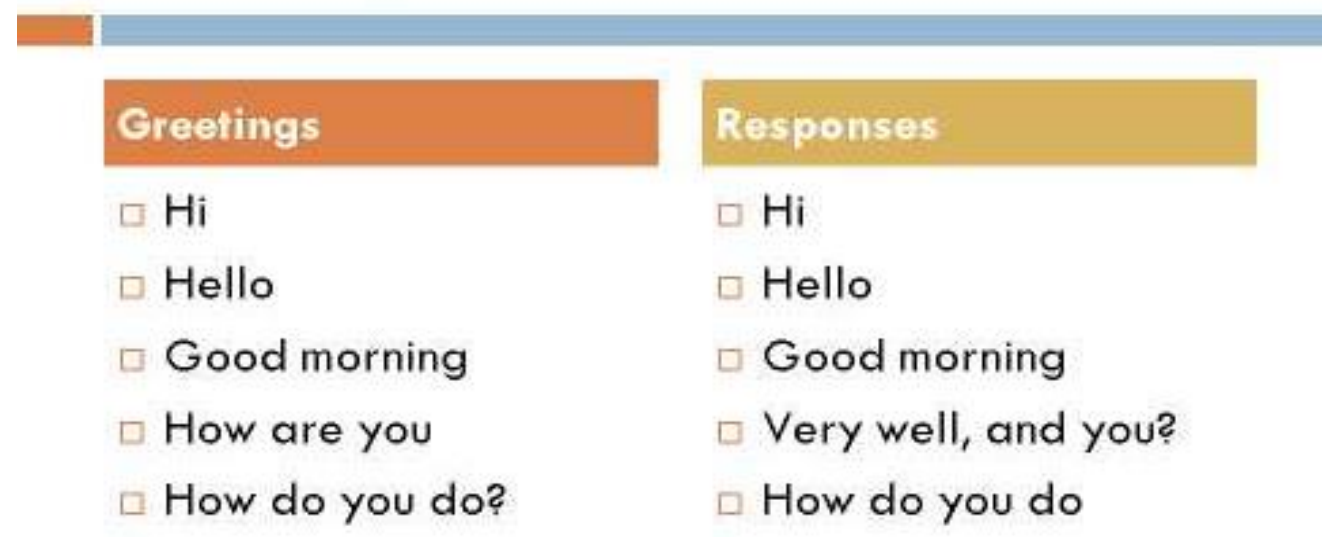

Gambar 4. Contoh halaman Handout dan Slide PPT

\section{SIMPULAN DAN TINDAK LANJUT}

Pelatihan dilaksanakan dengan baik, tanpa ada halangan yang berarti. Metode pembelajaran menyenangkan juga dilaksanakan dengan baik. Setiap tahapan dalam metode pembelajaran menyenangkan, mulai dari tahap background knowledge, modelling, joint 
construction dan independent construction pun dilaksanakan dengan baik. Berbagai metode pembelajaran juga telah dilaksanakan dengan lancar, antara lain: direct method, drilling dan collaborative learning.

Melihat dari segi asertif, peserta antusias dalam mengikuti pelatihan ini dan mengharapkan adanya pelatihan tambahan di lain kesempatan. Dari tingkat kehadiran, peserta tetap aktif berangkat mengikuti pelatihan ini. Dari bebrapa pertemuan, banyak peserta yang aktif bertanya dan aktif berdiskusi dalam pelatihan. Setelah selesai pelatihan, peserta menjadi lebih percaya diri Ketika menggunakan bahasa Inggris. Mereka sudah tidak terlihat canggung untuk berbicara menggunakan bahasa Inggris di depan teman-temannya.

Dengan selesainya pelatihan ini, diharapkan para peserta pelatihan akan lebih giat berlatih bahasa Inggris dan lebih sering membaca. Peserta juga diharapkan akan lebih sering mengunjungi perpustakaan daerah setelah mengetahui fasilitas yang ada dalam DINARPUSDA tersebut. Ada baiknya kegiatan pelatihan serupa bisa dilaksanakan secara berkala memgingat banyaknya sekolah di sekitar area DINARPUSDA. Pelatihan lain yang juga memungkinkan dan diminati adalah pelatihan public speaking yang tentunya dibutuhkan para siswa untuk meningkatkan kemampuan berkomunikasi.

\section{DAFTAR PUSTAKA}

Aini, E. N., Isnaini, I., Sukamti, S., \& Amalia, L. N. (2018). Pengaruh Tingkat Pendidikan Terhadap Tingkat Kesejahteraan Masyarakat di Kelurahan Kesatrian Kota Malang. Technomedia Journal,3(1),58-72. https://doi.org/10.33050/tmj.v3i1.333

Alek, A. (2014). Perspektif Baru Pengajaran Bahasa Inggris Melalui Direct Method: Sebuah Kajian Kritis. Lentera Pendidikan: Jurnal Ilmu Tarbiyah dan Keguruan, 17(2), 153-166. https://doi.org/10.24252/lp.2014v17n2a1.

Andy, A., Rusfandi, R., \& Muzammil, L. (2018). Pelatihan berbahasa Inggris dengan drilling dan repetition bagi Karang Taruna Desa Jedong. Martabe: Jurnal Pengabdian Kepada Masyarakat, 1(2), 42-48. https://doi.org/10.31604/jpm.v1i2.42-48

Cahyati, A. (2015). Analisis Ilustrasi Gambar Pada Buku Teks Fisika Kelas Xi Yang Banyak Digunakan Di Sma Negeri Se-Kabupaten Demak. UPEJ (Unnes Physics Education Journal), 4(3). https://doi.org/10.15294/upej.v4i3.8181

Elly, E. (2013). Peningkatan Kemampuan Berbicara Melalui Metode Drill Pada Pembelajaran Bahasa Indonesua Kelas IV Sekolah Dasar Usaba Sepotong. In FKIP Universitas Tanjungpura.

hulu, f., \& Ambalegin, A. (2018). EFEKTIVITAS DIRECT METHOD DALAM PENINGKATAN KEMAMPUAN BERBICARA BAHASA INGGRIS MAHASISWA. JURNAL BASIS, 5(2), 21-32. doi:10.33884/basisupb.v5i2.814.

Latifah, S. (2019). Interelasi Keterampilan Berbicara Terhadap Kemampuan Komunikasi Peserta Didik dalam Pembelajaran Bahasa Indonesia. Prosiding SENASBASA (Seminar Nasional Bahasa Dan Sastra), 3, 980-990.

Layyinah, L. (2017). Menciptakan Pembelajaran Fun Learning Based on Scientific Approach dalam Pembentukan Karakter Peserta Didik pada Pembelajaran PAI. TARBAWY: Indonesian Journal of Islamic Education, 4(1), 1-9. https://doi.org/10.17509/t.v4i1.6987

Lestari, S. D. (2019). Pendampingan Pembelajaran Bahasa Inggris Dasar Pada Eks-TKI Di Dusun Sumberwaru Desa Tamanagung Kecamatan Cluring Kabupaten Banyuwangi. JATI EMAS (Jurnal Aplikasi Teknik Dan Pengabdian Masyarakat), 3(1), 38. https://doi.org/10.36339/je.v3i1.188

Muliyah, P., \& Fernando, F. (2019). Pelatihan Pengenalan Bahasa Inggris Untuk Anak Usia Dini 
Melalui IGRA. DEDIKASI: Jurnal Pengabdian Masyarakat, 1(1), 20-36.

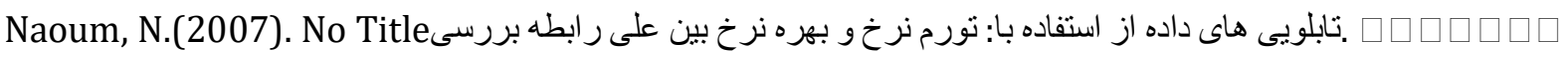

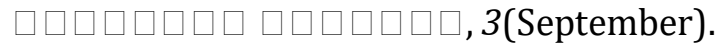

Nasional, U. S. P. (1982). Introduction and Aim of the Study. Acta Pædiatrica, 71, 6-6. https://doi.org/10.1111/j.1651-2227.1982.tb08455.x

Permata, N. N., \& Hsdiani, D. (2018). Pelatihan Bahasa Inggris Dasar Dalam Upaya Peningkatan Kemampuan Mahasiswa Bidikmisi POLMAN Bandung. Jurnal Pengabdian Kepada Masyarakat, 2(4). http://jurnal.unpad.ac.id/pkm/article/view/19781/9596

Hum, R. M. PELATIHAN BAHASA INGGRIS MELALUI MEDIA GAMBAR DENGAN DIRECT METHOD (METODE LANGSUNG).

Suniati, A'am Rifaldi Khunaifi, \& Setiawan, D. (2017). Bahasa Inggris Berekuivalen TOEFL Terhadap Mahasiswa Universitas Muhammadiyah Palangkaraya. PengabdianMu, 2(1), 4752. http://jurnal.umpalangkaraya.ac.id/ejurnal/pgbmu

Tamrin, A. F., \& Yanti, Y. (2019). Peningkatan keterampilan bahasa Inggris masyarakat pegunungan di Desa Betao Kabupaten Sidrap. Transformasi: Jurnal Pengabdian Masyarakat, 15(2), 61-72. https://doi.org/10.20414/transformasi.v15i2.1673

Warman, J. S., Mardian, V., Suryani, L., Fista, F. R., \& Irwan, I. (2019). Program Pelatihan Penigkatan Kemampuan Bahasa Inggris Anak-Anak Panti Asuhan Melalui Pemberdayaan Mahasiswa. Dinamisia: Jurnal Pengabdian Kepada Masyarakat,3(2), 280-285. https://doi.org/10.31849/dinamisia.v3i2.3304

Widyastuti, A. (2012). Analisis Hubungan Antara Produktivitas Pekerja Dan Tingkat Pendidikan Pekerja Terhadap Kesejahteraan Keluarga Di Jawa Tengah Tahun 2009. Economics Development Analysis Journal, 1(2). https://doi.org/10.15294/edaj.v1i2.472 